\title{
Building Awareness of the Impact of Environmental Xenobiotics in Coal-Fired Flue Gas
}

\author{
Cornelia A. Bulucea ${ }^{1}$, , Marc A. Rosen ${ }^{2}$, Nikos E. Mastorakis ${ }^{3}$, Carmen A. Bulucea ${ }^{4}$, Corina \\ C. Brindusa ${ }^{4}$ and Andreea C. Jeles ${ }^{5}$ \\ 1 University of Craiova, Faculty of Electrical Engineering, Craiova 200440, Romania; \\ 2 Faculty of Engineering and Applied Science, University of Ontario Institute of Technology, \\ Oshawa, ON, L1H 7K4, Canada; \\ 3 Technical University of Sofia, Industrial Engineering Department, Sofia, Bulgaria \& Military \\ Institutions of University Education (ASEI), Hellenic Naval Academy, Piraeus 18539, Greece; \\ 4 University of Medicine and Pharmacy of Craiova, Craiova 200349, Romania; \\ 5 Technical College of Arts and Crafts "Constantin Brancusi" of Craiova, Craiova 200135, Romania. \\ E-Mails: abulucea@em.ucv.ro (C.A.B.); marc.rosen@uoit.ca (M.R.); mastor@tu-sofia.bg (N.M.); \\ carmen.bulucea@umfcv.ro (C.B.); corinaa_b@yahoo.com (C.C.B.); andreee_83@yahoo.com (A.J.)
}

* Author to whom correspondence should be addressed: E-Mail: abulucea@em.ucv.ro (C.A.B.); Tel.: $+40-724-751-952$

Received: 15 August 2014 / Accepted: 13 October 2014 / Published: 1 November 2014

\begin{abstract}
Dangerous and unstable situations can result from the presence of environmental xenobiotics since their harmful effects on humans and ecosystems are often unpredictable. The environmental xenobiotics in the flue gas from a fossil fuel-fired electrical generating station, such as particulate matter $(\mathrm{PM})$, sulfur dioxide $\left(\mathrm{SO}_{2}\right)$, nitrogen oxides $\left(\mathrm{NO}_{\mathrm{x}}\right)$, and carbon dioxide $\left(\mathrm{CO}_{2}\right)$, are analyzed in this study, since these xenobiotics are persistentent pollutants. Mathematical models of the environmental pollutant vector, estimating the emission factors specific to fossil fuel combustion, are applied to the operation of thermal units in the Turceni electrical generating station, each of which produce a net electrical power of $330 \mathrm{MW}$. For each stack gas component in the pollutant vector, emission factor and pollutant concentration are determined. A pattern is also examined depicting the mathematically modelled processes of resonant absorption of an environmental xenobiotic harmonic oscillation by an organism modulated as an absorbing oscillator structure. The xenobiotic concentration degree is represented through a spatial concentration vector, which
\end{abstract}


allows further modelling and simulation of the oscillating regime of environmental xenobiotic absorption.

Keywords: coal, environmental xenobiotics, electrical generating station, environmental impact, flue gas, pollutant vector

\section{Introduction}

Thermoelectric power generation in a coal-fired plant involves the conversion of thermal energy to electrical energy. Coal is used to heat a liquid to produce a high pressure vapour (usually water is heated to produce steam) which is then expanded through a turbine that drives an electric generator [13]. The combustion, or flue, gas is exhausted to the outside through a chimney. Flue gas is usually composed of carbon dioxide, water vapour and nitrogen, as well as sulfur oxides, nitrogen oxides, particulate matter and carbon monoxide [1-4].

It is increasingly accepted globally that, within the present industrial metabolism, electric and thermal energy generation, as a main consumer of fossil fuels in general and coal in particular, is causing environmental problems because of emissions [1,5,6]. As a major source of sulfur oxides, coal-fired electrical generating stations represent a large contributor to acid precipitation. Coal-fired industrial operations are also a significant source of nitrogen oxides, with an impact comparable to that of transportation [4-6]. Hence, the combustion of coal strongly contributes to acid precipitation and climate change due to global warming [5]. Furthermore, the health of humans and other life forms is impacted of burning coal in electrical generating stations, and is a serious concern.

Over the last several decades, the term xenobiotic has become increasingly accepted as relating to environmental impact [7,8]. Environmental xenobiotics are substances foreign to a biological system, which did not exist in nature before their synthesis by humans. In this context, xenobiotics are persistent pollutants, and the components of flue gas fall within this scope. Dangerous and unstable situations can result from the presence of environmental xenobiotics since their harmful effects on humans and ecosystems are often unpredictable [7-9]. Hence, the immune system as a whole can be the target for xenobiotic induced toxicity, since environmental xenobiotics have the capacity to suppress the body's defence against reactive chemicals and pathogenic microorganisms. This suppression can cause increased susceptibility to cancer or autoimmune diseases. Moreover, environmental xenobiotics may be associated with endocrine alterations in people and wildlife. Yet few studies on environmental xenobiotics have been reported for energy systems, and more information is needed to avoid the potential problems they can cause. In this paper, therefore, we use mathematical models for the metabolism analysis of environmental xenobiotics represented by the environmental emissions (particulate matter, sulfur dioxide and nitrogen oxides) during the operation of coal-fired power stations.

\section{Flue Gas Pollutant Vector for a Coal-fired Electrical Generating Station}


Flue gas monitoring during the operation of a coal-fired power plant is an essential step in assessing the impact of environmental xenobiotics. Here, we examine the case of the Turceni electrical generating station $[4,10]$ in Romania, which is lignite-fired. Three distinct operating conditions are considered:

1) Operation of the Turceni power plant at $33.33 \%$ of the installed power capacity (i.e., at 660 MW), which corresponds to two thermoelectric units ( $n=2)$ of 330 MW each in operation for an hour; flue gas from the two thermoelectric units pass through one chimney.

2) Operation of the Turceni power plant at $66.66 \%$ of the installed power capacity (i.e., at 1320 MW), which corresponds to four thermoelectric units $(n=4)$ of $330 \mathrm{MW}$ each in operation for an hour; flue gas from the four thermoelectric units pass through two chimneys.

3) Operation of the Turceni power plant at full installed power capacity (i.e., at $1980 \mathrm{MW}$ ), which corresponds to six thermoelectric units $(n=6)$ of $330 \mathrm{MW}$ each in operation for an hour; flue gas from the six thermoelectric units pass through three chimneys in this case.

\subsection{Flue Gas Assessment with SEDD Methodology}

This study deals with the flue gas pollutant vector, and the assessment of the pollutant emissions (as a source of environmental xenobiotics) from the Turceni power plant. We use the Strategy and Economic Development Division (SEDD) methodology, which is described in the Romanian Electrical Department as calculation method PE-1001 [21]. The methodology is based on the models that depict the emission factors for fuel combustion processes [11]. For distinct pollutants the emission factors are determined experimentally.

The flow rate of a pollutant released to the atmosphere $E_{P o l}$ is determined (in $\mathrm{kg} / \mathrm{h}$ ) as $[1,4,10,11]$ :

$$
E_{P o l}=B \cdot H_{i C} \cdot e_{P o l}
$$

where $B$ is the fuel flow rate (in $\mathrm{kg} / \mathrm{h}$ ), $H_{i C}$ is the lower calorific value of the fuel (in $\mathrm{kJ} / \mathrm{kg}$ ), and $e_{P o l}$ is the emission factor (in $\mathrm{kJ} / \mathrm{kg}$ ).

The mass concentration of a pollutant released by combustion is determined (in $\mathrm{mg} / \mathrm{m}_{\mathrm{N}}{ }^{3}$ ) as:

$$
C_{m P o l}=E_{P o l} \cdot 10^{6} / D_{\text {Gaze }}
$$

where $D_{\text {Gaze }}$ is the volumetric flow rate of combustion gases (in $\mathrm{m}_{\mathrm{N}}^{3} / \mathrm{h}$ ).

Mathematical models in the SEDD methodology have been used to depict emission factors for fuel combustion in the thermoelectric units of the Turceni power plant. The following operating conditions are assumed in this case study:

a) The fuel is lignite (a type of coal) with a lower calorific value $H_{i L}=6280 \mathrm{~kJ} / \mathrm{kg}$, and the following composition: sulfur $\mathrm{S}=0.8 \%$, carbon $\mathrm{C}=20 \%$, ash $\mathrm{A}=25.5 \%$ and total moisture $\mathrm{W}=45 \%$.

b) The consumption rate of coal for a $330 \mathrm{MW}$ thermoelectric unit is determined on the basis of the medium flow rate of pulverized coal by the 5 coal mills $(5 * 92.6 \mathrm{t} / \mathrm{h}=463 \mathrm{t} / \mathrm{h})$, and accordingly the lignite flow rate is $B_{L}=463 \mathrm{t} / \mathrm{h}$.

c) Oil is utilized as a fuel support and has a lower calorific value $H_{i P}=39,770 \mathrm{~kJ} / \mathrm{kg}$ and the following composition: sulfur $\mathrm{S}=3 \%$ and carbon $\mathrm{C}=76 \%$.

d) The consumption rate of oil for a $330 \mathrm{MW}$ thermoelectric unit is $B_{P}=10^{*} 10^{3} \mathrm{~kg} / \mathrm{h}$. 
The flue gas pollutant vector has four main environmental xenobiotic components: sulfur dioxide $\mathrm{SO}_{2}$, carbon dioxide $\mathrm{CO}_{2}$, particulate matter PM and nitrogen oxides NOx.

\subsubsection{Component $\mathrm{SO}_{2}$ of Pollutant Vector}

The SEDD methodology yields the following results: the emission factor for the pollutant $\mathrm{SO}_{2}$ by lignite combustion $e_{\mathrm{LSO}_{2}}[\mathrm{~kg} / \mathrm{kJ}]$, the flow rate of $\mathrm{SO}_{2}$ from by lignite combustion $E_{\mathrm{LSO}_{2}}[\mathrm{~kg} / \mathrm{h}]$, the emission factor for $\mathrm{SO}_{2}$ by oil combustion $e_{P_{S O}}[\mathrm{~kg} / \mathrm{kJ}]$, the flow rate $\mathrm{of}_{\mathrm{SO}_{2}}$ from oil combustion $E_{\mathrm{PSO}_{2}}[\mathrm{~kg} / \mathrm{h}]$, the total flow rate of $\mathrm{SO}_{2}$ from combustion $E_{\mathrm{SO}_{2}}[\mathrm{~kg} / \mathrm{h}]$, and the mass concentration of pollutant $\mathrm{SO}_{2}$ from combustion $C_{m S O_{2}}\left[m g / m_{N}^{3}\right]$. In Table 1 , the resulting data for this case study are listed for the xenobiotic component $\mathrm{SO}_{2}$ of the flue gas pollutant vector.

Table 1. Data for $\mathrm{SO}_{2}$ component of flue gas

\begin{tabular}{|c|c|c|c|c|c|c|c|}
\hline Parameter & Symbol & Unit & Fuel type & Reference value & Case I $(n=2)$ & Case II $(n=4)$ & Case III $(n=6)$ \\
\hline Lignite: fuel flow rate & $B_{L}$ & $\mathrm{~kg} / \mathrm{h}$ & lignite & $463 * 10^{3}$ & $926 * 10^{3}$ & $1852 * 10^{3}$ & $2778 * 10^{3}$ \\
\hline Oil: fuel flow rate & $B_{P}$ & $\mathrm{~kg} / \mathrm{h}$ & oil & $10 * 10^{3}$ & $20 * 10^{3}$ & $40 * 10^{3}$ & $60 * 10^{3}$ \\
\hline $\begin{array}{l}\text { Lignite: } \mathrm{SO}_{2} \text { emission } \\
\text { factor }\end{array}$ & $e_{\mathrm{LSO} 2}$ & $\mathrm{~kg} / \mathrm{kJ}$ & lignite & $2.04 * 10^{-6}$ & $2.04 * 10^{-6}$ & $2.04 * 10^{-6}$ & $2.04 * 10^{-6}$ \\
\hline $\begin{array}{l}\text { Lignite: } \mathrm{SO}_{2} \text { pollutant } \\
\text { flow rate }\end{array}$ & $E_{L S O 2}$ & $\mathrm{~kg} / \mathrm{h}$ & lignite & 5930 & 11.860 & 23.720 & 35.580 \\
\hline $\begin{array}{l}\text { Oil: } \mathrm{SO}_{2} \text { emission } \\
\text { factor }\end{array}$ & $e_{\mathrm{PSO} 2}$ & $\mathrm{~kg} / \mathrm{kJ}$ & oil & $1.51 * 10^{-6}$ & $1.51 * 10^{-6}$ & $1.56 * 10^{-6}$ & $1.51 * 10^{-6}$ \\
\hline $\begin{array}{l}\text { Oil: } \mathrm{SO}_{2} \text { pollutant } \\
\text { flow rate }\end{array}$ & $E_{P S O 2}$ & $\mathrm{~kg} / \mathrm{h}$ & oil & 600 & 1200 & 2400 & 3600 \\
\hline $\begin{array}{l}\text { Total flow rate of } \mathrm{SO}_{2} \\
\text { pollutant }\end{array}$ & $E_{\mathrm{SO} 2}$ & $\mathrm{~kg} / \mathrm{h}$ & all fuels & 6530 & 13.060 & 26.120 & 39.180 \\
\hline $\begin{array}{l}\text { Concentration of } \mathrm{SO}_{2} \\
\text { pollutant }\end{array}$ & $C_{m S O 2}$ & $\mathrm{mg} / \mathrm{m}^{3}{ }_{\mathrm{N}}$ & all fuels & 3840 & 3840 & 3840 & 3840 \\
\hline
\end{tabular}

\subsubsection{Component $\mathrm{CO}_{2}$ of Pollutant Vector}

Based on the same methodology, the resulting data for carbon dioxide are listed in Table 2.

Table 2. Data for $\mathrm{CO}_{2}$ component of flue gas

\begin{tabular}{|l|l|l|l|l|l|l|l|}
\hline Parameter & Symbol & Unit & Fuel type & Reference value & Case I $(\mathrm{n}=2)$ & Case II $(\mathrm{n}=4)$ & Case III (n=6) \\
\hline Lignite: fuel flow rate & $B_{L}$ & $\mathrm{~kg} / \mathrm{h}$ & lignite & $463 * 10^{3}$ & $926 * 10^{3}$ & $1852 * 10^{3}$ & $2778 * 10^{3}$ \\
\hline Oil: fuel flow rate & $B_{p}$ & $\mathrm{~kg} / \mathrm{h}$ & oil & $10 * 10^{3}$ & $20 * 10^{3}$ & $40^{*} 10^{3}$ & $60 * 10^{3}$ \\
\hline $\begin{array}{l}\text { Lignite: } \mathrm{CO}_{2} \text { emission } \\
\text { factor }\end{array}$ & $e_{L C O 2}$ & $\mathrm{~kg} / \mathrm{kJ}$ & lignite & $116.8 * 10^{-6}$ & $116.8 * 10^{-6}$ & $116.8 * 10^{-6}$ & $116.8 * 10^{-6}$ \\
\hline Lignite: $\mathrm{CO}_{2}$ pollutant & $E_{L C O 2}$ & $\mathrm{~kg} / \mathrm{h}$ & lignite & 33.960 & 67.920 & 135.840 & 203.760 \\
\hline
\end{tabular}




\begin{tabular}{|l|l|l|l|l|l|l|l|}
\hline flow rate & & & & & & & \\
\hline $\begin{array}{l}\text { Oil: } \mathrm{CO}_{2} \text { emission } \\
\text { factor }\end{array}$ & $e_{P C O 2}$ & $\mathrm{~kg} / \mathrm{kJ}$ & oil & $70.1 * 10^{-6}$ & $70.1 * 10^{-6}$ & $70.1 * 10^{-6}$ & $70.1 * 10^{-6}$ \\
\hline $\begin{array}{l}\text { Oil: } \mathrm{CO}_{2} \text { pollutant } \\
\text { flow rate }\end{array}$ & $E_{P C O 2}$ & $\mathrm{~kg} / \mathrm{h}$ & oil & 27.880 & 55.760 & 111.520 & 167.280 \\
\hline $\begin{array}{l}\text { Total flow rate of } \mathrm{CO}_{2} \\
\text { pollutant }\end{array}$ & $E_{C O 2}$ & $\mathrm{~kg} / \mathrm{h}$ & all fuels & 61.840 & 123.680 & 247.360 & 371.040 \\
\hline $\begin{array}{l}\text { Concentration of } \mathrm{CO}_{2} \\
\text { pollutant }\end{array}$ & $C_{m C O 2}$ & $\mathrm{mg} / \mathrm{m}^{3}$ & all fuels & 36.380 & 36.380 & 36.380 & 36.380 \\
\hline
\end{tabular}

\subsubsection{Component PM of Pollutant Vector}

Table 3 shows the resulting data for the particulate matter (PM) component of the pollutant vector.

Table 3. Data for PM component of flue gas

\begin{tabular}{|c|c|c|c|c|c|c|c|}
\hline Parameter & Symbol & Unit & Fuel type & Reference value & Case I $(n=2)$ & Case II $(n=4)$ & Case III $(n=6)$ \\
\hline Lignite: fuel flow rate & $B_{L}$ & $\mathrm{~kg} / \mathrm{h}$ & lignite & $463 * 10^{3}$ & $926 * 10^{3}$ & $1852 * 10^{3}$ & $2778 * 10^{3}$ \\
\hline Oil: fuel flow rate & $B_{P}$ & $\mathrm{~kg} / \mathrm{h}$ & oil & $10 * 10^{3}$ & $20 * 10^{3}$ & $40 * 10^{3}$ & $60 * 10^{3}$ \\
\hline $\begin{array}{l}\text { Lignite: PM emission } \\
\text { factor }\end{array}$ & $e_{P M}$ & $\mathrm{~kg} / \mathrm{kJ}$ & lignite & $0.345 * 10^{-6}$ & $0.345^{*} 10^{-6}$ & $0.345^{*} 10^{-6}$ & $0.345 * 10^{-6}$ \\
\hline $\begin{array}{l}\text { Lignite: PM pollutant } \\
\text { flow rate }\end{array}$ & $E_{P M}$ & $\mathrm{~kg} / \mathrm{h}$ & lignite & 1003 & 2006 & 4012 & 6018 \\
\hline $\begin{array}{l}\text { Concentration of PM } \\
\text { pollutant }\end{array}$ & $C_{m P M}$ & $\mathrm{mg} / \mathrm{m}^{3}{ }_{\mathrm{N}}$ & all fuels & 590 & 590 & 590 & 590 \\
\hline
\end{tabular}

\subsubsection{Component $\mathrm{NO}_{x}$ of Pollutant Vector}

Based on the same methodology, the resulting data for nitrogen oxides are listed in Table 4.

Table 4. Data for $\mathrm{NO}_{\mathrm{x}}$ component of flue gas

\begin{tabular}{|l|l|l|l|l|l|l|}
\hline Parameter & Symbol & Unit & Fuel type & Case I $(\mathrm{n}=2)$ & Case II $(\mathrm{n}=4)$ & Case III $(\mathrm{n}=6)$ \\
\hline Lignite: fuel flow rate & $B_{L}$ & $\mathrm{~kg} / \mathrm{h}$ & lignite & $926^{*} 10^{3}$ & $1852 * 10^{3}$ & $2778 * 10^{3}$ \\
\hline Oil: fuel flow rate & $B_{P}$ & $\mathrm{~kg} / \mathrm{h}$ & oil & $20 * 10^{3}$ & $40^{*} 10^{3}$ & $60^{*} 10^{3}$ \\
\hline Lignite: $\mathrm{NO}_{\mathrm{x}}$ emission factor & $e^{80}{ }_{\text {NNOx }}$ & $\mathrm{kg} / \mathrm{kJ}$ & lignite & $2.44 * 10^{-7}$ & $2.44 * 10^{-7}$ & $2.44 * 10^{-7}$ \\
\hline Lignite: $\mathrm{NO}_{\mathrm{x}}$ pollutant flow rate & $E_{L N O x}$ & $\mathrm{~kg} / \mathrm{h}$ & lignite & 1420 & 2840 & 4260 \\
\hline Oil: $\mathrm{NO}_{\mathrm{x}}$ emission factor & $e^{80}{ }_{P N O x}$ & $\mathrm{~kg} / \mathrm{kJ}$ & oil & $2.52 * 10^{-6}$ & $2.52^{*} 10^{-6}$ & $2.52^{*} 10^{-6}$ \\
\hline Oil: $\mathrm{NO}_{\mathrm{x}}$ pollutant flow rate & $E_{P N O x}$ & $\mathrm{~kg} / \mathrm{h}$ & oil & 200 & 400 & 600 \\
\hline Total flow of $\mathrm{NO}_{\mathrm{x}}$ pollutant & $E_{N O x}$ & $\mathrm{~kg} / \mathrm{h}$ & all fuels & 1620 & 3240 & 4860 \\
\hline Concentration of $\mathrm{NO}_{\mathrm{x}}$ pollutant & $C_{m N O x}$ & $\mathrm{mg} / \mathrm{m}^{3} \mathrm{~N}$ & all fuels & 480 & 480 & 480 \\
\hline
\end{tabular}




\subsection{Projection in Mirror of Flue Gas Pollutant Vector}

The flue gas pollutant vector is depicted [4,10-12] by origin, direction, sense and magnitude:

- the pollutant vector origin is represented by the gases exiting the power plant chimney;

- the pollutant vector direction has a temporal character and is defined mainly by climate factors, wind speed being the most important;

- the pollutant vector sense is defined by the evacuation chimney for the combustion gases; and

- the pollutant vector magnitude is determined by the concentration of pollutants and varies spatially, decreasing with increasing distance from the chimney.

The projection in mirror of the pollutant vector allows the evaluation of the mass concentration of ash in the flue gases leaving the chimney, at distances of several hundred meters [4,10-12]. The combustion gas inside the chimney represents the flue gas, which on dispersion into the air becomes an environmental pollutant vector. From the viewpoint of contaminating the surroundings, it is important to estimate the dispersion in the atmosphere of the pollutant components of the flue gas. One could accept an optical representation of the flue gas pollutant vector as a projection in mirror of the chimney flue gas, with the symmetry axis as the tangent to the top of stack (see Fig. 1).

Figure 1. Symmetry axis A-A for combustion gas chimney. Combustion gas wedge $\alpha=45^{0}$

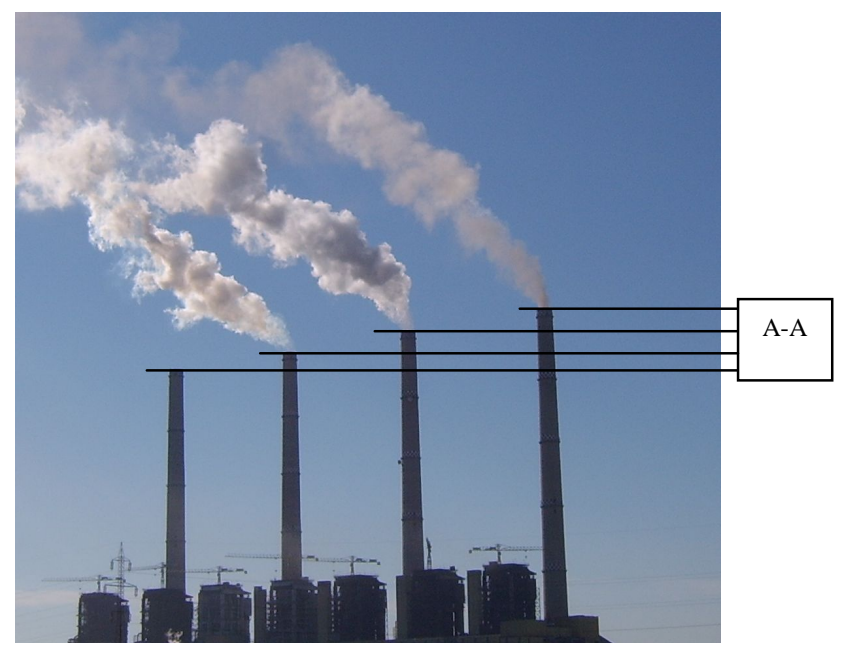

For this purpose, we note that the longitudinal section of a power station chimney has a trapezoidal shape, the chimney height is roughly $300 \mathrm{~m}$, and on the chimney surface there are markings at intervals of 50 meters. In line with same idea, one could note that the flue gas component concentrations increase with height of chimney. This approach permits the flue gas leaving the chimney (representing the environmental pollutant vector) to be equated to a symmetrical body like a truncated cone (see Fig. 2).

Due to this optical analogy, on the truncated cone that models the flue gas exhausted by the chimney, we can establish iso-mass domains of ash (PM) concentration.

Note that the concentrations of ash and combustion gases are inversely proportional to the truncated cone height. 
In the present case study of the $330 \mathrm{MW}$ units of the Turceni thermoelectric generating station, the projection in mirror is developed for distances of 300 meters (see Fig. 2 and Table 5).

The distribution of iso-mass curves in the case of the projection in the mirror for isomorphic curves on the order of $100 \mathrm{mg} / \mathrm{m}_{N}^{3}$ in the flue gas is depicted in Fig. 2.

Figure 2. Iso-mass curves: $\mathrm{IsO}_{500}, \mathrm{IsO}_{400}, \mathrm{IsO}_{300}, \mathrm{Iso}_{200}, \mathrm{Iso}_{100}$

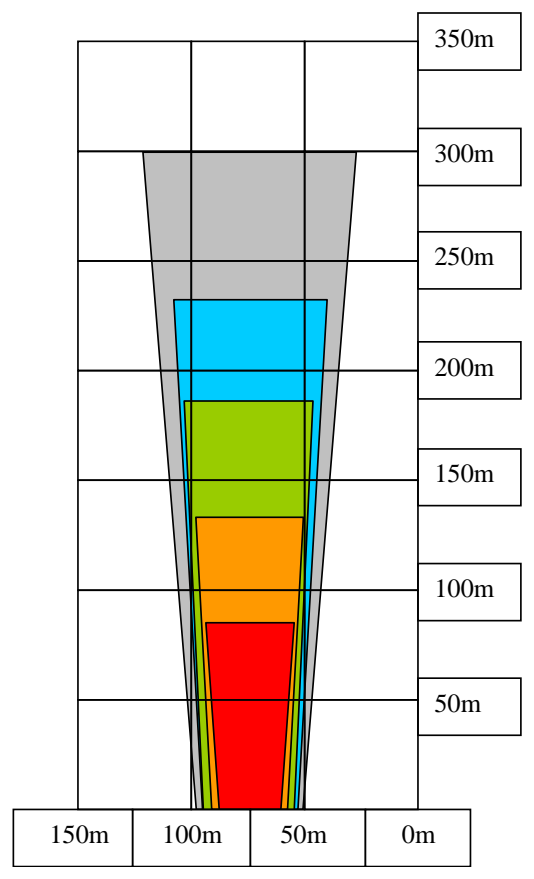

Table 5. Distribution of iso-mass curves in flue gas pollutant vector

\begin{tabular}{|c|c|c|c|c|c|}
\hline No. & $\begin{array}{c}\text { Iso- } \\
\text { mass } \\
\text { curves }\end{array}$ & $\begin{array}{c}\text { Iso }= \\
\text { Iso-mass } \\
\text { indicative }\end{array}$ & $\begin{array}{c}\mathrm{C}_{\mathrm{m}}\left[\mathrm{mg} / \mathrm{m}^{3}{ }_{\mathrm{N}}\right]= \\
\text { maximum } \\
\text { concentation }\end{array}$ & $\begin{array}{c}\mathrm{k}\left[\mathrm{m}^{-2}\right]= \\
\text { correction } \\
\text { factor }\end{array}$ & $\begin{array}{c}\mathrm{Z}-\mathrm{Z}_{\mathrm{c}}[\mathrm{m}]= \\
\text { distance on } \\
\text { iso-mass } \\
\text { curve }\end{array}$ \\
\hline 1 & IsO $_{500}$ & 500 & 590 & 0,00002 & 85 \\
\hline 2 & Iso $_{400}$ & 400 & 590 & 0,00002 & 135 \\
\hline 3 & Iso $_{300}$ & 300 & 590 & 0,00002 & 185 \\
\hline 4 & Iso $_{200}$ & 200 & 590 & 0,00002 & 235 \\
\hline 5 & Iso $_{100}$ & 100 & 590 & 0,00002 & 300 \\
\hline
\end{tabular}

To determine the mass concentration evolution via the projection in mirror of the flue gas pollutant vector, patterns of diffusion predictions are developed [11-13] that permit appropriate comparisons with experimental data from laboratory tests.

To model the ascendant flue gas exhausted by the chimney in this paper according to the projection in mirror at a distance of 300 meters, we use the pattern of probability density function (PDF), elaborated by Weil [12]. This model allows parameters to be input for phenomena that govern pollutant dispersion into the atmosphere. As an example, the overall nomogram for the mass 
concentration of ash-particulate matter from the Turceni power plant is depicted in Fig. 3 when two thermal units are in operation $(n=2)$.

Figure 3. Overall nomogram of mass concentration for ash-particulate matter from the Turceni power plant $(\mathrm{n}=2)$

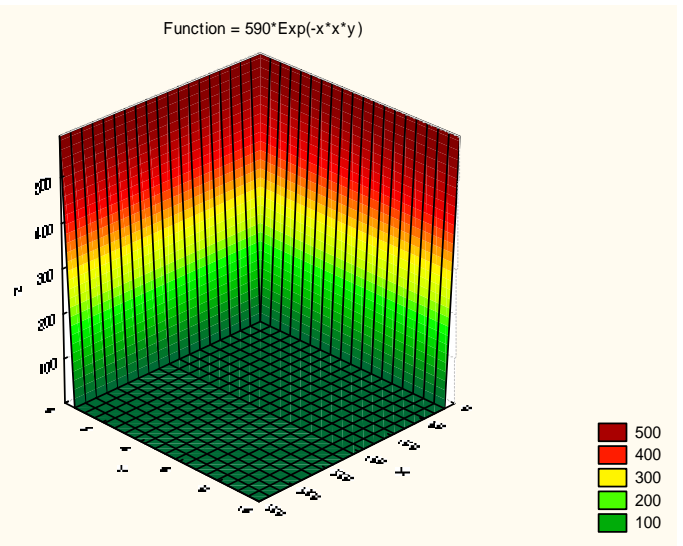

The simulation takes into account two variables:

- the variable $\mathrm{x}$ which is represented by the distance on the iso-mass curve $\left(\mathrm{z}-\mathrm{z}_{\mathrm{c}}\right)[\mathrm{m}]$; $\left.{ }^{2}\right]$.

- the variable $\mathrm{y}$ which is denoted by $\mathrm{k}=$ correction factor, with values in the range $10^{-5}$ to $10^{-4}\left[\mathrm{~m}^{-}\right.$

Note also that: $\mathrm{z}[\mathrm{m}]$ represents the calculation height of the flue gases leaving the chimney; $\mathrm{z}_{\mathrm{c}}[\mathrm{m}]$ is the chimney height; and $\left(\mathrm{z}-\mathrm{z}_{\mathrm{c}}\right)[\mathrm{m}]$ is the distance on the iso-mass curve. The simulation result is the value of the multivariable function denoted by $C\left[\mathrm{mg} / \mathrm{m}^{3}\right]$ which represents the mass concentration remaining at the distance $\left(z-z_{c}\right)[m]$ from the flue gas chimney. Furthermore, $C_{m}\left[\mathrm{mg} / \mathrm{m}^{3}\right]$ is the maximum mass concentration at the point in which the flue gases are leaving the chimney.

\subsection{Testing Validation and Discussion}

For the above mentioned conditions, to validate the acceptability of the results from the SEDD methodology, it is necessary to compare the simulation results with experimental data. For this purpose, we developed an experimental validation of the mathematical pattern evaluation of flue gas xenobiotic components using data obtained by the Calcination Evaluation Stand together with data from the Chemical Laboratory - Coal Section of the Turceni electrical generating station [10,11].

The concentrations of flue gas xenobiotics leaving the chimney as sulfur dioxide $\left(\mathrm{SO}_{2}\right)$, carbon dioxide $\left(\mathrm{CO}_{2}\right)$, particulate matter (PM) and nitrogen oxides $\left(\mathrm{NO}_{\mathrm{x}}\right)$ are depicted in Tables 6, 7, 8 and 9, respectively.

Table 6. Testing data for $\mathrm{SO}_{2}$ xenobiotic component of flue gas

\begin{tabular}{|l|l|l|l|l|l|}
\hline Parameter & Symbol & Unit & Sample I & Sample II & Sample III \\
\hline $\mathrm{SO}_{2}$ emission factor & $\mathrm{e}_{\mathrm{LSO} 2}$ & $\mathrm{~kg} / \mathrm{kJ}$ & $2.02 * 10^{-6}$ & $2.06 * 10^{-6}$ & $2.1 * 10^{-6}$ \\
\hline $\begin{array}{l}\text { Concentration of } \\
\text { pollutant } \mathrm{SO}_{2}\end{array}$ & $\mathrm{C}_{\mathrm{mSO} 2}$ & $\mathrm{mg} / \mathrm{m}^{3} \mathrm{~N}$ & 3802 & 3878 & 3955 \\
\hline
\end{tabular}


Table 7. Testing data for $\mathrm{CO}_{2}$ xenobiotic component of flue gas

\begin{tabular}{|l|l|l|l|l|l|}
\hline Parameter & Symbol & Unit & Sample I & Sample II & Sample III \\
\hline $\begin{array}{l}\mathrm{CO}_{2} \text { emission } \\
\text { factor }\end{array}$ & $e_{\mathrm{LCO} 2}$ & $\mathrm{~kg} / \mathrm{kJ}$ & $114.5^{*} 10^{-6}$ & $119.1 * 10^{-6}$ & $120.3 * 10^{-6}$ \\
\hline $\begin{array}{l}\text { Concentration of } \\
\text { pollutant } \mathrm{CO}_{2}\end{array}$ & $C_{m C O 2}$ & $\mathrm{mg} / \mathrm{m}^{3}{ }_{\mathrm{N}}$ & 35652 & 37108 & 37471 \\
\hline
\end{tabular}

Table 8. Testing data for PM xenobiotic component of flue gas

\begin{tabular}{|l|l|l|l|l|l|}
\hline Parameter & Symbol & Unit & Sample I & Sample II & Sample III \\
\hline $\begin{array}{l}\text { PM emission } \\
\text { factor }\end{array}$ & $e_{P M}$ & $\mathrm{~kg} / \mathrm{kJ}$ & $0.335^{*} 10^{-6}$ & $0.355^{*} 10^{-6}$ & $0.359 * 10^{-6}$ \\
\hline $\begin{array}{l}\text { Concentration of } \\
\text { pollutant PM }\end{array}$ & $C_{m P M}$ & $\mathrm{mg} / \mathrm{m}^{3}{ }_{\mathrm{N}}$ & 572 & 608 & 614 \\
\hline
\end{tabular}

Table 9. Testing data for $\mathrm{NO}_{\mathrm{x}}$ xenobiotic component of flue gas

\begin{tabular}{|l|l|l|l|l|l|}
\hline Parameter & Symbol & Unit & Sample I & Sample II & Sample III \\
\hline $\begin{array}{l}\mathrm{NO}_{\mathrm{x}} \text { emission } \\
\text { factor }\end{array}$ & $e_{L N O x}$ & $\mathrm{~kg} / \mathrm{kJ}$ & $2.41 * 10^{-7}$ & $2.49 * 10^{-7}$ & $2.51 * 10^{-7}$ \\
\hline $\begin{array}{l}\text { Concentration of } \\
\text { pollutant } \mathrm{NO}_{\mathrm{x}}\end{array}$ & $C_{m N O x}$ & $\mathrm{mg} / \mathrm{m}^{3} \mathrm{~N}$ & 475 & 490 & 495 \\
\hline
\end{tabular}

The analysis was carried out for three samples and, according to the data depicted as above, the following mean values are determined from burning lignite for each xenobiotic component of the flue gas pollutant vector:

a) Sulfur dioxide $\left(\mathrm{SO}_{2}\right)$ xenobiotic: emission factor $e_{\mathrm{LSO}_{2}}=2.06^{*} 10^{-6} \mathrm{~kg} / \mathrm{kJ}$; pollutant concentration $C_{\mathrm{mSO}_{2}}=3878 \mathrm{mg} / \mathrm{m}^{3} \mathrm{~N}$; average error $\varepsilon_{\text {mean }} \leq 1 \%$; maximum error $\varepsilon_{\max } \leq 3 \%$.

b) Carbon dioxide $\left(\mathrm{CO}_{2}\right)$ xenobiotic: emission factor $e_{\mathrm{LCO}_{2}}=118^{*} 10^{-6} \mathrm{~kg} / \mathrm{kJ}$; pollutant concentration $C_{m \mathrm{CO}_{2}}=36744 \mathrm{mg} / \mathrm{m}^{3}{ }_{\mathrm{N}}$; average error $\varepsilon_{\text {mean }} \leq 1 \%$; maximum error $\varepsilon_{\max } \leq 3 \%$.

c) Particulate matter $(\mathrm{PM})$ xenobiotic: emission factor $e_{P M}=0.35^{*} 10^{-6} \mathrm{~kg} / \mathrm{kJ}$; pollutant concentration $C_{m P M}=598 \mathrm{mg} / \mathrm{m}^{3}{ }_{\mathrm{N}}$; average error $\varepsilon_{\text {mean }} \leq 1.5 \%$; maximum error $\varepsilon_{\max } \leq 4 \%$.

d) Nitrogen oxides $\left(\mathrm{NO}_{\mathrm{x}}\right)$ xenobiotic: emission factor $e_{L N O_{x}}=2.47 * 10^{-7} \mathrm{~kg} / \mathrm{kJ}$; pollutant concentration $C_{m N O_{x}}=487 \mathrm{mg} / \mathrm{m}^{3}{ }_{\mathrm{N}}$; average error $\varepsilon_{\text {mean }} \leq 1.5 \%$; maximum error $\varepsilon_{\max } \leq 3 \%$.

\section{Linear Mathematical Model of Xenobiotics Absorption Process}

Xenobiotics have been extended to the environment over the last several decades, with many studies [7-9] demonstrating that xenobiotics relate to environmental impact. This is especially valid in the 
context of pollutants, many of which are substances foreign to a biological system that did not exist in nature before their synthesis by humans.

Environmental xenobiotics are becoming increasingly problematic in medicine and environmental systems, since they are relatively new substances and difficult to categorize, and since it is challenging to assess their effects on human health and the environment [7-8].

As shown in previous sections, coal-fired power plants emit particulate matter, $\mathrm{SO}_{2}, \mathrm{NO}_{\mathrm{x}}$ as well as gases that undergo chemical reactions to form fine particles in atmosphere [3-5,14]. These reactive chemicals (particulate matter, sulfur dioxide and nitrogen oxides) represent environmental xenobiotics, which spread over hundreds to thousands of kilometers downwind of power plants. In addition to the environmental harm caused by greenhouse gases and other emissions, the air emissions of coal-fired power stations encompass a certain amount of toxic xenobiotics that result in significant numbers of human deaths and diseases [7-9]. Through exposure to these environmental xenobiotics, people can experience heart disease, respiratory illness and lung cancer, as well as such other health problems as adverse reproductive outcomes, infant death, chronic bronchitis, asthma, and other lung diseases $[4,6,15]$. As a consequence, the pollutant load from environmental xenobiotics concerns researchers in medical and environmental fields.

The immune system is extremely vulnerable and sensitive to modulation by environmental xenobitics. Various experimental assays can be performed to ascertain the immunotoxic potential of environmental xenobiotics, accounting for genetic factors, xenobiotic penetration route, and amount and duration of exposure, as well as the xenobiotic wave shape [7-8]. In this paper, we propose an approach for the analysis of xenobiotic metabolism using mathematical models and corresponding methods. Here, we focus on a pattern depicting mathematically modelled processes of resonant absorption of a xenobiotic harmonic oscillation by an organism modulated as an absorbing oscillator structure [16]. We represent the xenobiotic concentration degree through a spatial concentration vector, and model and simulate the oscillating regime of environmental xenobiotic absorption.

By analogy with thermal physics, where the temperature difference gives the sense and magnitude of the transferred energy, the main vector of behavioural analysis in the event of an environmental xenobiotic "attack" is represented by the xenobiotic concentration $c(t)$. That is, to create a homogenous framework and problem definition, we address the percentage representation of the xenobiotic concentration through the spatial concentration vector $c(t)$. The mathematic model depicting such a vector could be linear or non-linear, as evidenced by the relation between the system input and output [17]. Note that a linear pattern respects the superposition principle and the homogeneity property.

Consider a mathematical model with the input quantities $x_{i}(t)$ and the output quantities $z_{i}(t)$. According to the superposition principle, the mathematical model is linear if the input $x(t)=x_{1}(t)+x_{2}(t)$ determines an output $z(t)=z_{1}(t)+z_{2}(t)$. Also, one can define the homogeneity property if for an input $\alpha \cdot x_{i}(t)$ the resulting output is $\alpha \cdot z_{i}(t)$, where $\alpha$ denotes the transfer coefficient or attenuation factor. Note that if we are dealing with nonlinear models, the pattern linearization through the tangent to the curve at an operation point can be achieved by developing a Taylor series of the function near this point. 


\section{Modelling and Simulation of Oscillating Regime of Environmental Xenobiotics Absorption}

We have shown $[16,19]$ that a mathematical model described by a differential equation of order two with concentration parameters $[18,19]$ is adequate for a complex process of environmental xenobiotic absorption by a linear structure. We have defined a hypothetical situation in which, from an environmental xenobiotic source with harmonic behaviour, the xenobiotic is absorbed by the biological organism modelled as a system with a linear structure $[16,19]$. The xenobiotic concentration has been subsequently denoted $z(t)$.

Within the structure of a modulated absorption system corresponding to the biological organism (the target of a xenobiotic), one can identify specific elements of xenobiotic compounds that are of a dissipating type or an accumulating type [16,19]. As stated earlier, a mathematical model depicting a xenobiotic absorption process could be a differential equation of order 2. Consequently, we have considered [16,19] an analogous pattern of physics, namely an electrical structure type RLC series circuit, where the accumulating elements are described by the capacity $C$ and the inductance $L$, while the dissipating elements are characterized by the resistance $R$ [16,18-20]. Note that we have considered a simplified hypothesis referring to a concentrated parameters circuit, connected to a harmonic source, with the possibility of defining the elements RLC in various ways.

The differential equation corresponding to this transient regime is as follows:

$$
L C \frac{d^{2} z}{d t^{2}}+R C \frac{d z}{d t}+z=Z_{m} \sin (\omega t+\psi)
$$

for which the simplified solution for xenobiotic concentration $[16,19]$ is expressed as:

$$
z(t)=Z_{m} \cos \omega t-Z_{m} \cos \omega_{0} t
$$

This expression emphasizes the superposition of two oscillating components, with the harmonic xenobiotic pulsation $\omega$ and the biologic system pulsation $\omega_{0}=\omega_{e}$, respectively.

The mathematical modelling stage is followed by the simulation of specific phenomena, using appropriate software. For instance, one could use MATLAB software with SIMULINK and SimPowerSystems extensions. Here, we developed a SIMULINK model entailing specific blocks generated by the SIMULINK library.

The explicit function (4) leads, based on the MATLAB-SIMULINK utility, to the simulation model for the spatial vector of concentration $z(t)$, depicted in Fig. 4. Based on the resulting simulation pattern, the representations of Figs. 5, 6 and 7 are obtained.

Figure 4. Simulation model for spatial vector of concentration. Case 1 


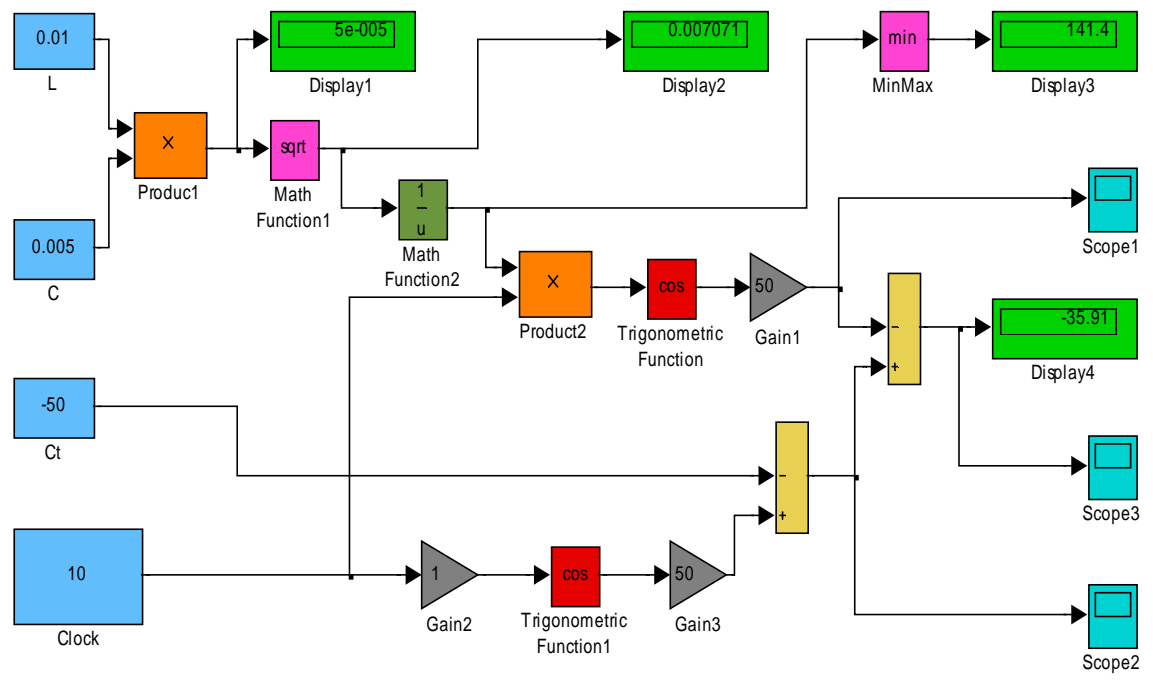

Figure 5. Modulating signal obtained on the basis of absorption circuit elements. Case 1

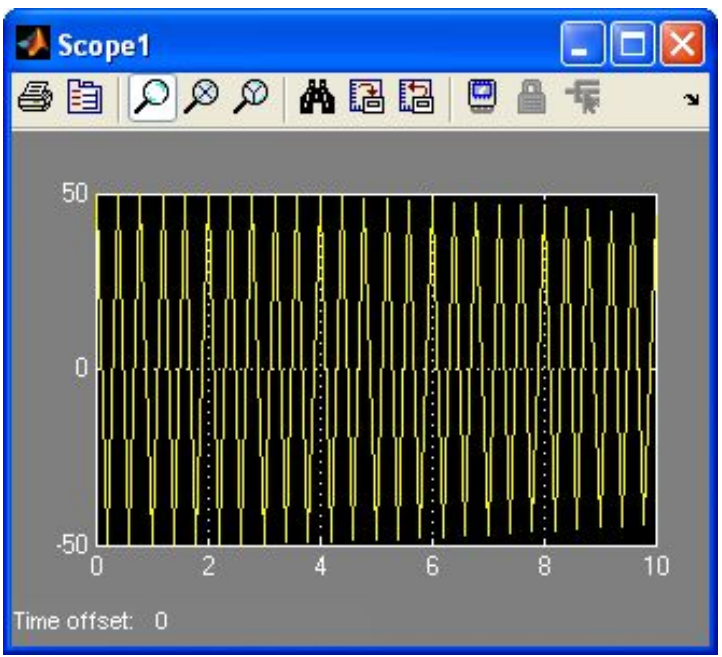

Figure 6. Harmonic oscillation of xenobiotic. Case 1

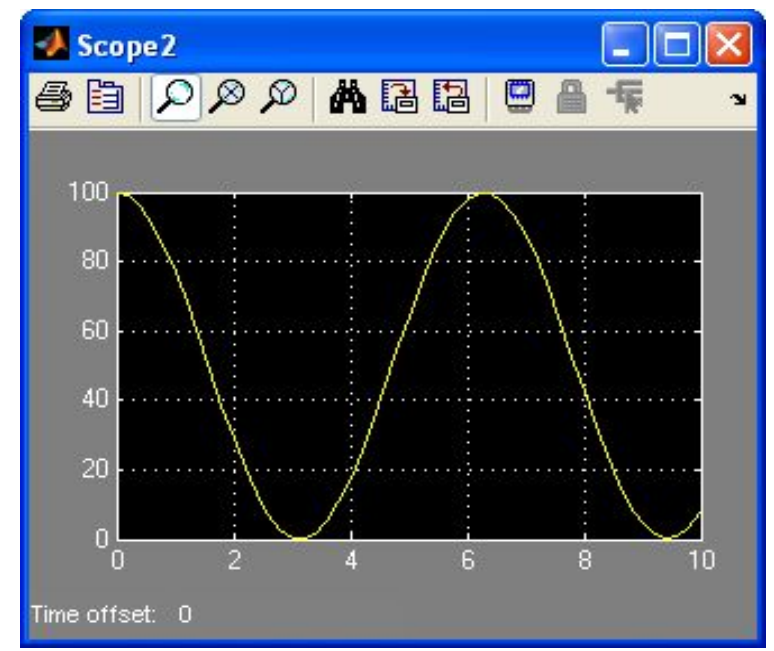


Figure 7. Simulation diagram for spatial vector of concentration $z(t)$. Case 1

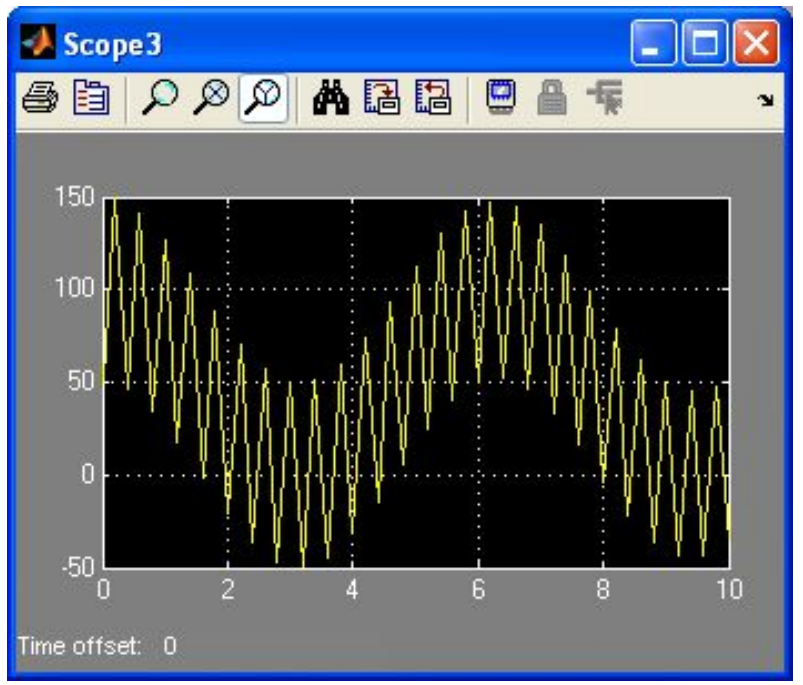

Fig. 5 depicts the modulating signal obtained on basis of absorption circuit elements corresponding to the biological system with resonant pulsation $\omega_{0}$.

In Fig. 6, the xenobiotic harmonic oscillation, with the pulsation $\omega$, is presented.

Fig. 7 shows the simulation diagram for the spatial vector of concentration $z(t)$, as resultant oscillation wave depicting the resonant absorption process of the environmental xenobiotic. This representation shows that, in the particular case of the resonant absorption of the harmonic environmental xenobiotic, the output can be amplified up to three times relative to the input. Note that to maintain a good degree of generality in this study we use quantities with relative values.

The results determine the variation in time of the spatial concentration vector $z(t)$ as periodic, with the wave shape determined by taking into consideration a modulation of the main excitation harmonic provided by the xenobiotic, and the resulting high frequency modulating signal on the basis of elements specific to a xenobiotic absorption circuit. It is observed that the spatial vector of concentration has a temporal variation of a harmonic modulated type, defined by the absorption medium.

The curves vary when the input parameters are changed.

Over time, practical technical difficulties have been observed in removing the impurities from the solid fuel prior to combustion, because of the chemical composition and structure of coal. Advanced technologies are continually being developed, with the aim of either (1) reducing power station emissions by implementing desulphurization technology, coal washing, and flue gas scrubbers and electrostatic precipitators that treat exhaust gases, or (2) applying carbon capture and storage to emissions from coal power stations. Even so, the environmental and human health impacts caused by the pollutant emission vector of coal-fired power plants are often unpredictable and dangerous if we consider the scenario of a sudden failure its pollution prevention technology. In line with this idea, we consider a second case study, in which the xenobiotic concentration shape exhibits a steep linearly rising slope (see Fig. 10). This increase of environmental xenobiotic concentration can determine (over a short time interval) an output amplification up to six times relative to the input, according to Fig. 11 (for the same study assumption, in which quantities with the same relative values are utilized so as to maintain a good degree of generality). 
Figure 8. Simulation model for spatial vector of concentration. Case 2

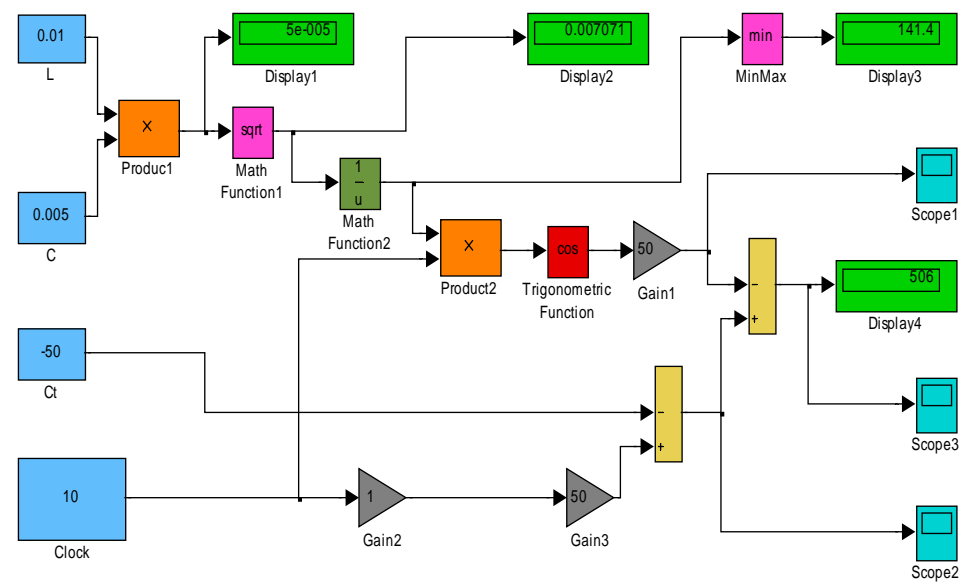

Figure 9. Modulating signal obtained on the basis of absorption circuit elements. Case 2

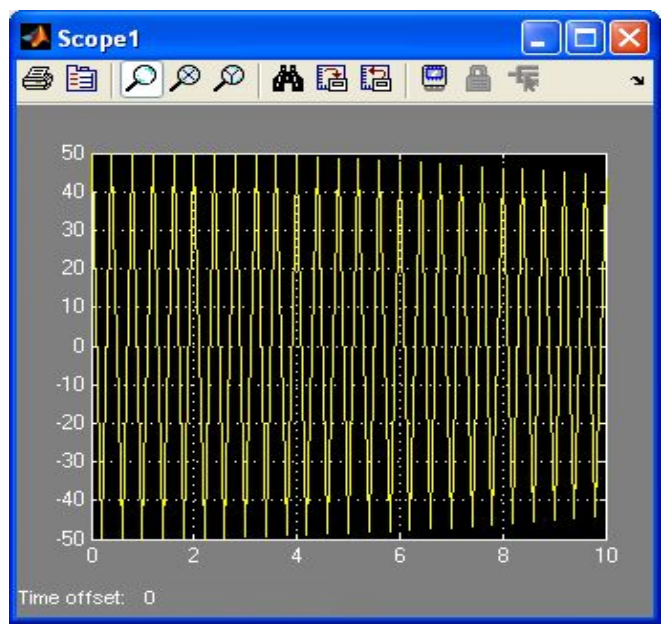

Figure 10. Xenobiotic shape evolution. Case 2

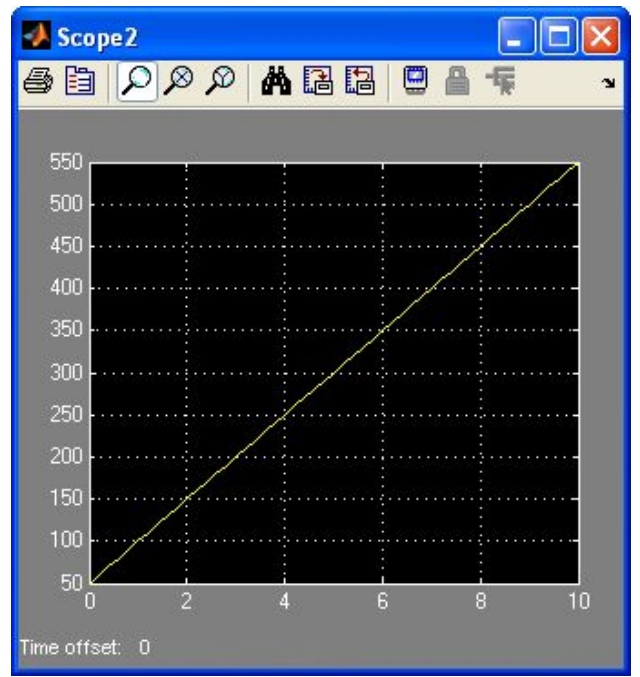


Figure 11. Simulation diagram for spatial vector of concentration $z(t)$. Case 2

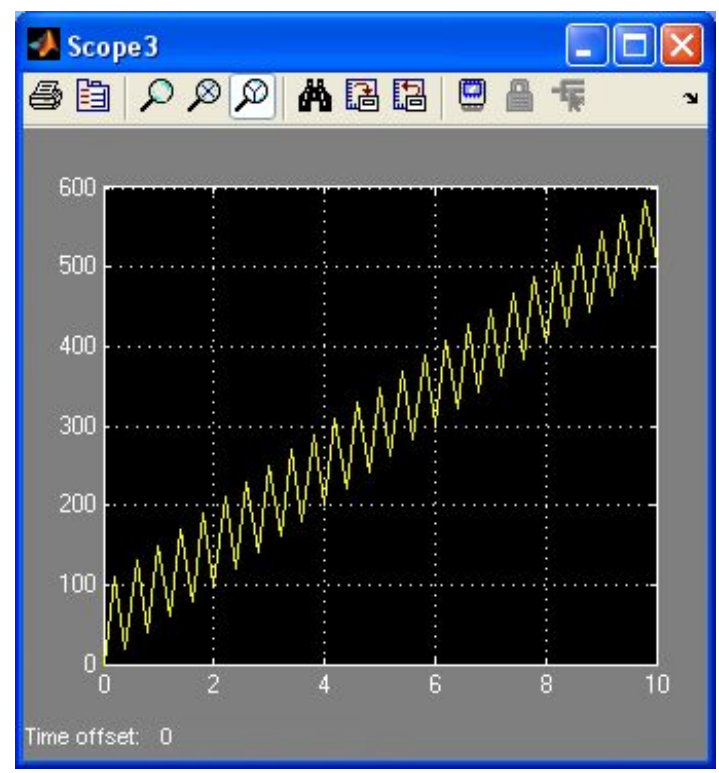

\section{Conclusions}

Flue gas monitoring during the operation of a coal-fired electrical generating station is an essential step in assessing the environmental and human health impact of pollutants.

Environmental xenobiotics from the flue gas of the coal-fired electrical generation stations are becoming increasingly problematic in medicine and environmental systems since, in addition to the environmental harm caused by greenhouse gases and other emissions, the flue gases contain toxic xenobiotics that result in significant perturbations of the immune system of humans and other life forms. The xenobiotic concentration evolution within a biological system is determined in the first case study assuming an environmental xenobiotic source with a harmonic behaviour, and an analogy with a linear structure characterized by xenobiotic compounds of both dissipating and accumulating types. It is anticipated that the results could be used to facilitate the assessment of the processes of environmental xenobiotic absorption, distribution, biotransformation and removal within the framework of compartmental analysis, by establishing appropriate mathematical models and simulations.

The simulations obtained in the second case study make it evident that all life forms surrounding an electrical generating station would be dramatically affected by a linear increase in the concentration of an environmental xenobiotic, represented by a compound of coal-fired flue gas, if pollution prevention equipment fails.

More generally, procedures should be implemented worldwide to estimate yearly emissions of primary particulate matter, sulfur oxides and nitrogen oxides, along with total electricity generation, for power plants. Also, since the flue gas from coal-fired power plants is dispersed over large areas, the population living around power plants should be included in databases. To improve sustainability, coal-fired electrical generating station should employ modern pollution control technology, where these end-of-pipe treatments can reduce environmental and human health impacts and avoid or retard 
the process of degradation of life on Earth, and cleaner production methods should be utilized to prevent pollution and reduce fuel consumption.

This study demonstrates the need for joint efforts by researchers in medicine, environmental engineering and computing for enhancing knowledge of the impacts of environmental xenobiotics on humans and other life forms.

\section{Conflict of Interest}

The authors declare no conflict of interest.

\section{References}

1. Dincer, I; Rosen, M.A, Exergy: Energy, Environment and Sustainable Development, 2d ed., Elsevier: Oxford, UK, 2013.

2. Rosen, M.A.; Bulucea, C.A. Using exergy to understand and improve the efficiency of electrical power technologies. Entropy, 2009, 11: 820-835.

3. Istrate, M.; Gusa, M. Impactul producerii, transportului si distributiei energiei electrice asupra mediulu (Environmental Impact of Electric Energy Generation and Transportation). AGIR Publishing House, Bucharest, 2000.

4. Rosen, M.A.; Dincer, I. Exergy analysis of waste emissions. Int. J Energy Research, 1999,. 23, 1153-1163.

5. Mishra, U.C. Environmental impact of coal industry and thermal power plants in India. Journal of Environmental Radioactivity, 2004, 72(1-2): 35-40.

6. Cohen, A.J.; Anderson, H.R.; Ostro, B.; Pandey, K.D.; Krzyzanowski, M.; Kunzli, N.; Gutschmidt, K.; Pope, A.; Romieeu, I.; Samet, J.M.; Smith, K. The global burden of disease due to outdoor air pollution. Journal of Toxicology and Environmental Health, Part A, 2005, 68: 1301-1307.

7. Nagarkatti, P.S.; Nagarkatti, M. Immunotoxicology: Modulation of the immune system by xenobiotics. Defence Science Journal, 1987, 37(2): 235-244.

8. Koller, L.D. Immunotoxicology today. Toxicologic Pathology, 1987, 15(3): 346-351.

9. Danzo, B.J. Environmental xenobiotics may disrupt normal endocrine function by interfering with the binding of physiological ligands to steroid receptors and binding proteins. Environmental Health Perspectives, 1997, 105(3): 294-301.

10. Bulucea, C.A.; Jeles, A.; Mastorakis, N.E.; Bulucea, C.A.; Brindusa, C. Assessing the environmental pollutant vector of combustion gases emission from coal-fired power plants. Recent Researches in Geography, Geology, Energy, Environment and Biomedicine - Proc. of the 4th WSEAS Int. Conf. on EMESEG'11, 2nd Int. Conf. on WORLD-GEO'11, 5th Int. Conf. on $E D E B^{\prime} 11$, Corfu Island, Greece, July 14-16, 2011, pp35-43,

11. Brînduşa, A.; Kovacs, J. Thermoenergetic block on coal. Pollution vector: burning gas. Annals of the University of Petrosani (Universitas Publishing House, Petroşani, Romania), 2007, 9: 218221.

12. Weil, J.C. A diagnosis of the asymmetry in top-down and bottom-up diffusion using a Lagrangian stochastic model. Journal of the Atmospheric Sciences, 1990, 47(4): 501-515. 
13. Breuil, J.M. Input-output analysis and pollutant emissions in France. The Energy Journal, 1992, 13: 173-184.

14. Hnatiuc, E. Procedes Electriques de Mesure et de Traitment des Polluant (Electrical Methods for Measurement and Treatment of Pollutants). Editions TEC\&DOC, Lavoisier Publishing House: Paris, France, 2002.

15. Penney, S.; Bell, J. Balbus, L. Estimating the health impacts of coal-fired power plants receiving international financing. Report of Environmental Defence Fund, Washington, DC, 2009.

16. Bulucea, C.A.; Rosen, M.A.; Mastorakis. N.E.; Bulucea, C.A.; Brindusa. C., Approaching Resonant Absorption of Environmental Xenobiotics Harmonic Oscillation by Linear Structure. Sustainability 2012, 4, 561-573

17. Niculescu, T. The Study of RLC Circuits Transitory Phenomena Using Matlab-Simulink Software. University of Petroşani Publishing House: Petrosani, Romania, 2005.

18. Nicola, D.A.; Bulucea, C.A. Electrotehnica, Echipamente si Masini Electrice (Electrotechnics, Electrical Equipment and Machines); Electrotehnica teoretica (Theoretical Electrotechnics). SITECH Publishing House: Craiova, Romania, 2005; volume I.

19. Bulucea, C.A.; Mastorakis, N.E.; Rosen, M.A.; Brindusa, C.; Bulucea, C.A.; Jeles, A. Enhancing Understanding of the Environmental Xenobiotics in Coal-Fired Flue Gas. Recent Researches in Environment and Biomedicine, Proceedings of the $6^{\text {th }}$ International Conferences on Energy and Development Environment- Biomedicine \{EDEB'12), Vouliagmeni, Greece, March 7-9, 2012, pp.58-67

20. Boashash, B. Editor, Time-Frequency Signal Analysis and Processing: A Comprehensive Reference. Elsevier Science, Oxford, 2003.

21. Metodologie de evaluare operativă a emisiilor de $\mathrm{SO}_{2}, \mathrm{NO}_{\mathrm{x}}$, pulberi (cenuşă zburătoare) şi $\mathrm{CO}_{2}$ din centrale termice şi termoelectrice (Methodology for operative evaluation of emissions of $\mathrm{SO}_{2}$, $\mathrm{NO}_{\mathrm{x}}$, particulate matter (fly ash) and $\mathrm{CO}_{2}$ in the thermal and electric power stations), Romanian Autonomous Electricity RENEL, Bucharest, 1994.

(C) 2014 by the authors; licensee MDPI, Basel, Switzerland. This article is an open access article distributed under the terms and conditions of the Creative Commons Attribution license. 